University of Nebraska - Lincoln

DigitalCommons@University of Nebraska - Lincoln

$5-1985$

\title{
Sedimentation in a Blast-Zone Lake at Mount St. Helens, Washington-Implications for Varve Formation
}

\author{
Roger Y. Anderson \\ University of New Mexico, ryand@unm.edu \\ Edward Nuhfer \\ Department of Geosciences, University of Wisconsin, Platteville, Platteville, Wisconsin 53818 \\ Walter E. Dean \\ U.S. Geological Survey, Denver, Colorado 80225
}

Follow this and additional works at: https://digitalcommons.unl.edu/usgsstaffpub

Part of the Earth Sciences Commons

Anderson, Roger Y.; Nuhfer, Edward; and Dean, Walter E., "Sedimentation in a Blast-Zone Lake at Mount St. Helens, Washington-Implications for Varve Formation" (1985). USGS Staff -- Published Research. 301. https://digitalcommons.unl.edu/usgsstaffpub/301

This Article is brought to you for free and open access by the US Geological Survey at DigitalCommons@University of Nebraska - Lincoln. It has been accepted for inclusion in USGS Staff -- Published Research by an authorized administrator of DigitalCommons@University of Nebraska - Lincoln. 


\title{
Sedimentation in a blast-zone lake at Mount St. Helens, Washington-Implications for varve formation
}

\author{
Roger $Y$. Anderson \\ Department of Geology, University of New Mexico, Albuquerque, New Mexico 87131 \\ Edward B. Nuhfer \\ Department of Geosciences, University of Wisconsin, Platteville, Platteville, Wisconsin 53818 \\ Walter E. Dean \\ U.S. Geological Survey, Denver, Colorado 80225
}

\begin{abstract}
Sediment collected in traps in a newly formed lake in the blast-impact area at Mount St. Helens recorded a sediment yield that is about two orders of magnitude greater than for comparable basins with vegetation and similar precipitation. Most sediment was mobilized by storms and runoff at the onset of the wet season. The sedimentation response to strongly seasonal precipitation, in the absence of vegetation, produced turbidites and graded annual couplets. The style of sedimentation suggests an alternate mechanism for the formation of long sequences of graded clastic varves.
\end{abstract}

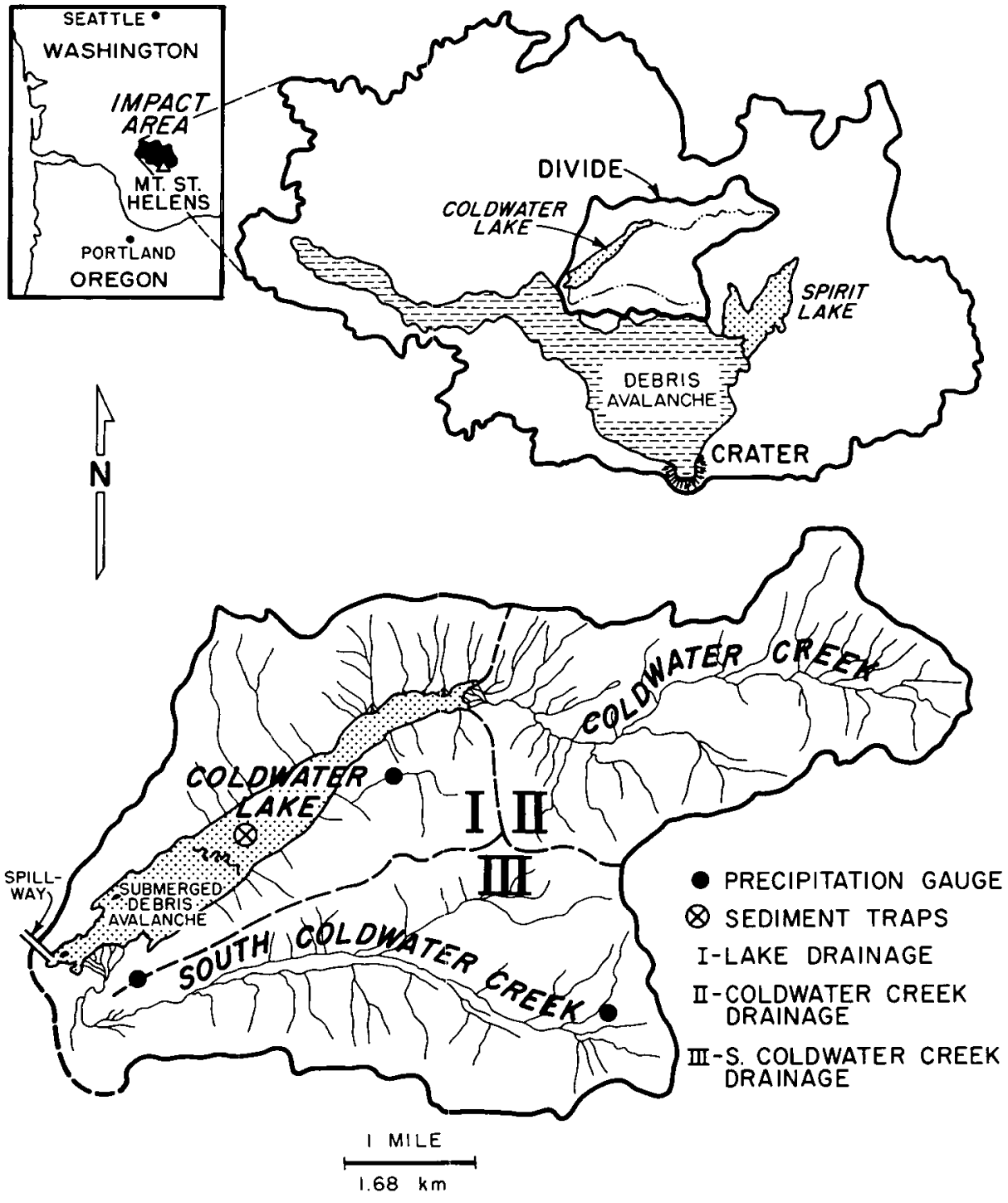

Figure 1. Blast impact area showing location of Coldwater Lake, drainage area, stream networks, sediment traps, and precipitation recording stations.

\section{INTRODUCTION}

The eruption of Mount St. Helens in southwestern Washington on May 18, 1980, was accompanied by a massive debris avalanche that impounded Coldwater and South Coldwater creeks and formed Coldwater Lake. The devastating lithopyroclastic surge felled trees and buried vegetation within an impact area that includes Coldwater Lake and its drainage (Fig. 1). The impoundment of Coldwater Lake has created an opportunity to examine the processes of erosion and deposition in a relatively large drainage under climatic conditions that are out of equilibrium with soils and vegetation. A sediment trap with a funnel shape that amplifies deposition and automatically marks intervals of time (Anderson, 1977; see also Fig. 2) was placed in Coldwater Lake on June 24, 1982, and recovered on August 4,1983 . The trap was replaced and recovered again on August 8, 1984. This report documents the strongly seasonal sedimentation response recorded in the traps and suggests that in the continued absence of vegetation, the graded clastic varves being formed would resemble those associated with a glaciolacustrine environment.

\section{COLDWATER LAKE AND DRAINAGE BASIN}

The basin that holds Coldwater Lake was formed when a debris avalanche from the May 18,1980 , eruption moved down the Toutle River and blocked the confluence of Coldwater and South Coldwater creeks. A tongue of the avalanche moved about $2 \mathrm{~km}$ up Coldwater valley. Coldwater Lake expanded to cover the valley floor and much of the debris avalanche in the valley. The Corps of Engineers stabilized the lake outlet with a spillway, and the lake 


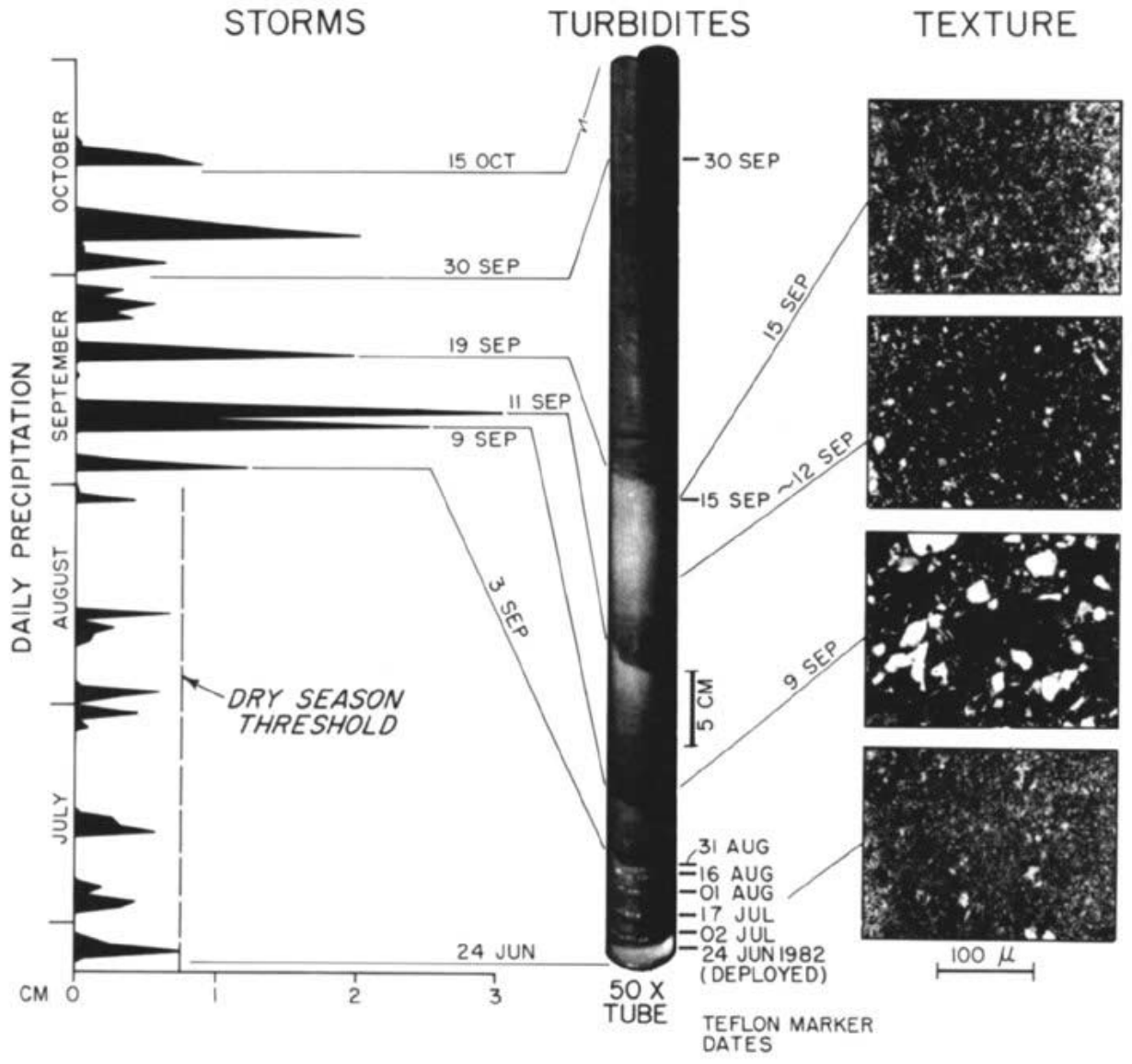

Figure 2. Correlation between daily precipitation and turbidite layers in $50 \times$ trap. Note that thickness of turbidite layer is proportional to size of storm. White Teflon layers seen near base of tube were inserted automatically to mark equal increments of time.

had risen to cover an area of $3.4 \mathrm{~km}^{2}$, had a maximum depth of $58 \mathrm{~m}$, and reached the spillway at the time the traps were deployed in June 1982 (Fig. 1).

The lake surface is at an elevation of $756 \mathrm{~m}$, the divides rising steeply to $1200-1500 \mathrm{~m}$. Stream gradients are commonly greater than $30^{\circ}$ in the $12.6-\mathrm{km}^{2}$ area that directly borders the lake and that is drained by first- and second-order streams. Coldwater and South Coldwater creeks are third-order streams that drain $14.0-\mathrm{km}^{2}$ and $16.3-\mathrm{km}^{2}$ areas, respectively. Average annual temperature at nearby Spirit Lake is $5.6^{\circ} \mathrm{C}$, annual precipitation is $225 \mathrm{~cm}$ at $1063 \mathrm{~m}$, and snowfall is $718 \mathrm{~cm}$ (U.S. Weather Bureau, 1980).

The upper South Fork of the Coldwater drainage is mantled by thick, highly erodible pyroclastic surge and density flow deposits that formed when an arm of the avalanche topped Johnston's Ridge (formerly Coldwater Ridge). Materials available for transport elsewhere are also easily eroded and contain a wide range of diameters. The slopes are mantled with air-fall blocks, lapilli, accretionary lapilli, and ash in layers $0.5 \mathrm{~m}$ to more than $2 \mathrm{~m}$ thick (Waitt, 1981). The density of dacite in the blast deposits ranges from 1.0 to $2.1 \mathrm{~g} / \mathrm{m}^{3}$, the average being between 1.6 and $1.8 \mathrm{~g} / \mathrm{m}^{3}$ (SarnaWojcicki et al., 1981). Dry pulverized samples of tephra from the drainage have a density of $1.4 \mathrm{~g} / \mathrm{cm}^{3}$.

The easily eroded materials in the South Coldwater drainage have resulted in overloaded streams on the flat valley floor. Deltas have formed where Coldwater and South Coldwater creeks enter the lake, the South Coldwater delta growing the fastest. Sediment yields were reported to be very high in the first runoff season after the eruption during initial gullying and when the finest materials were stripped from the slopes (Swanson et al., 1983). By the time the traps were deployed in June 1982, yield was probably reduced several fold.

Vegetation was virtually absent from the devastated area after the eruption. In the downtimber area, which includes the Coldwater drainages, only a small percentage of plants growing from rootstock (geophytes) survived. By late 1982, control plots in the fireweedpearly everlasting community still contained $62 \%$ bare ground (A. B. Adams, personal commun.). In August 1983 and 1984, when the traps were recovered, vegetation was established on the slopes, but large areas of bare ground were present in flat areas at lower elevations and in places where timber was unharvested prior to the blast.

\section{SEDIMENT TRAPS}

Two funnel-shaped, amplifying sediment traps of a design used by Anderson (1977) were suspended in the water $2.3 \mathrm{~m}$ above the bottom in the deepest part of the lake (Fig. 1). Trap openings were $25 \mathrm{~cm}$ and $7.5 \mathrm{~cm}$ in diameter, and the magnification ratios (ratio of trap-collecting area to sample-tube area) were $50 / 1$ and $4.25 / 1$. The larger trap contained a device that automatically dispensed marking granules of Teflon into the sample tube to mark intervals of 15 days (Fig. 2). Formalin buffered with sodium borate was placed in the sample tube as a preservative. The trap with a $50 / 1$ amplifying ratio collected sediment for 168 days before the sample tube filled. The $4.25 / 1$ trap collected the entire record of sedimentation. Comparison of trap samples with core samples in other lakes has shown that the record in the traps is more detailed but contains the same events found in bottom sediments (Kidd and Potter, 1978).

\section{DRY-SEASON DEPOSITION}

The larger 50/1 trap contained a remarkably clear record of the events that preceded and accompanied the first substantial precipitation at the onset of autumn rains. Before the rains began, sedimentation in the lake was slow (Table 1) and uniform (Fig. 2) and consisted of clay-sized volcanogenic material accompanied by the accumulation of phytoplankton, zooplankton, pollen, and other endogenic materials. Deposition in the lake was relatively unaffected by brief summer rainfalls. Three U.S. Geological Survey weather-recording stations within the Coldwater drainage provided precipitation data. A comparison of the precipitation and deposition records reveals a threshold of about $0.75 \mathrm{~cm}$ of precipitation per day for storms that generally lasted from 1 to 3 days (Fig. 2). Storms that exceeded this threshold at the onset of the wet season carried sediment to the deeper part of the lake.

\section{TURBIDITE DEPOSITION}

The 1982 dry season ended when strong storms arrived early in September. The first three storms to exceed the runoff threshold produced well-defined turbidite layers (Fig. 2). The runoff from these storms created a flow of suspended material into the lake that carried 
TABLE 1. SEDIMENTATION RATES AND YIELDS

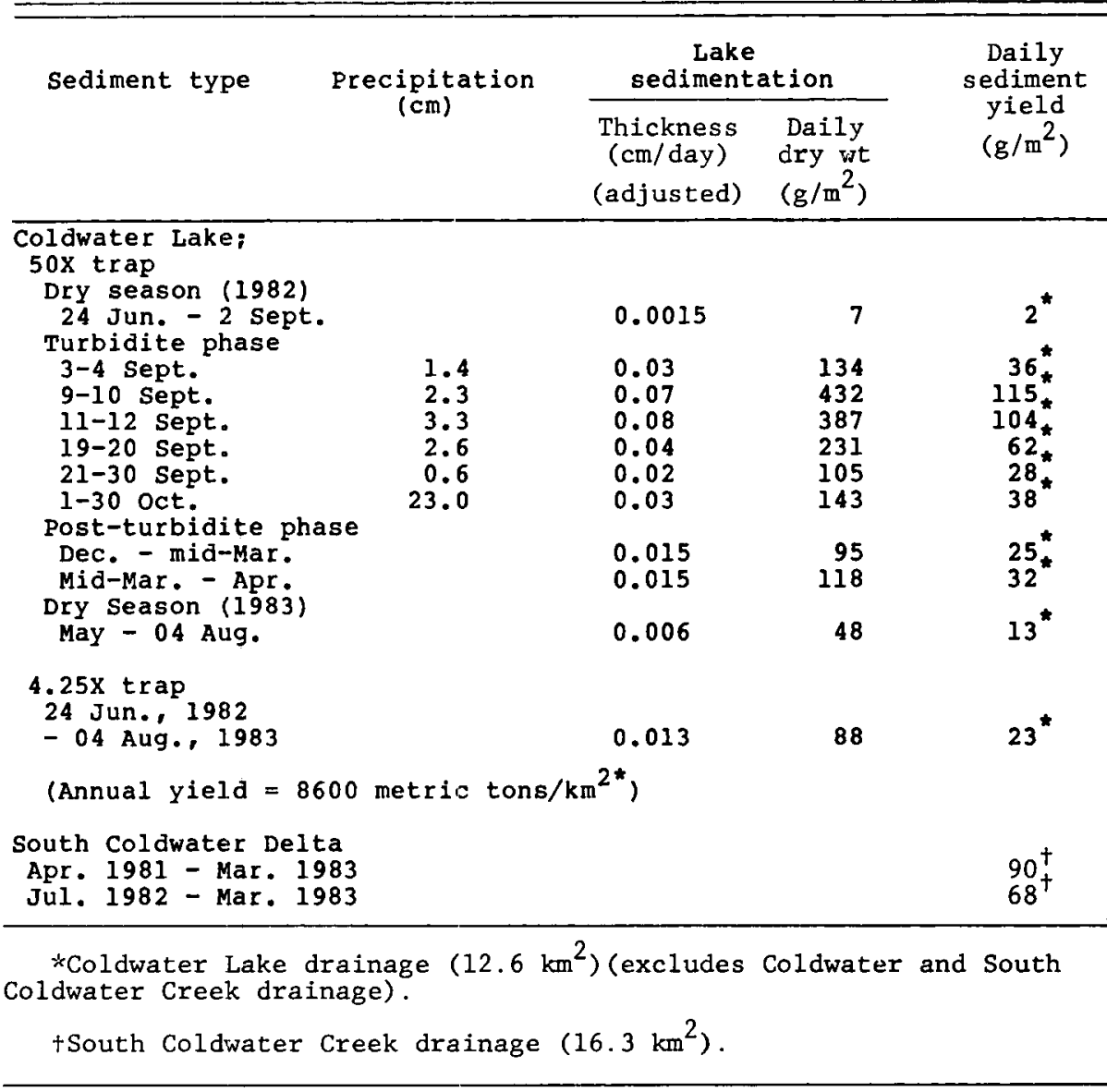

medium and fine silt-size sediment to the opening of the trap. The same event was repeated at the beginning of the wet season in 1983, when slightly less-well-defined turbidites were deposited in October and November.

A gravity core was taken at the trap location in August 1984. Penetration of the core into the coarse to medium silt, containing patches of fine sand, stopped in a woody trash layer at a depth of $35 \mathrm{~cm}$. The material collected represents a single depositional sequence, grading upward to fine silt and clay, and contains an unvarying pollen assemblage. Comparison with the material in the sediment trap indicates that the core sample is equivalent to no more than $6 \mathrm{~cm}$ of the sediment (corrected for amplification) collected through the trap opening $2.3 \mathrm{~m}$ above the bottom. This suggests that turbidite sediment reached the trap locality largely through bottom flow in the lake, that only a fraction of the flow was sampled by the trap, and that the true rate of sedimentation in the deepest part of the lake may be as much as six times faster than recorded in the trap.

The automatic dispensing of Teflon granules into the sampling tube permits a comparison of the record caught in the trap with storms and runoff during the wet season. The timing provided by the 15 -day markers has identified the three turbidites of the wet season was proportional to the magnitude of the storm (Fig. 2). By late September 1982, the runoff threshold may have been lowered, perhaps from saturation of soils, because a storm of the same magnitude as during the dry season carried additional sediment to the trap before the September $\mathbf{3 0}$ time marker was inserted.

The turbidites lost clear definition in late September 1982 and by mid October 1983 and gave way to more subtle alternations of silt and clay, which continued during the remainder of the wet season (Fig. 3). The early September storms and flows of sediment carried coarser sediment and greater suspended loads than even larger storms on December 3 and 16, 1982 , and January 5, 1983. The result was sharply defined turbidites at the onset of the wet season and poorly defined layers later in the season. A similar "first flush" effect has been observed directly in small, steep, mountain streams where bedload movement per unit of discharge is greatest prior to peak flow. In addition, suspended sediment concentration per storms and shows that the thickness of the first unit of discharge is known to decline progressively after peak flow, and the critical discharge required to entrain bedload increases as the runoff season continues (Nanson, 1974). The seasonal decline of sediment yield into Coldwater Lake from this effect can be seen by comparing precipitation during storms with trap loadings for the same storms in the turbidite phase of deposition (Table 1).

The decline in coarser grain sizes that was associated with lower sediment yields as the runoff season progressed was chiefly responsible for the loss of definition of the turbidites. The end of the wet season brought a return to the deposition of clay similar in appearance to that observed during the previous dry season. The increased rate of dry-season deposition in 1983 as compared to the previous year was apparently due to the more persistent rainfall in the summer of 1983 . The dry-season rate, however, is still an order of magnitude slower than at the onset of the wet season (Table 1).

\section{SPRING STORM OR MASS TRANSPORT EVENT}

A layer of coarse sediment consisting of sand-size pumice fragments, shards, and woody plant debris was carried to the trap sometime in the early spring of 1983 (Fig. 3). Pumice grains between 0.5 and $0.8 \mathrm{~mm}$ are common in this material. A sequence of photographs taken during the 1982-1983 trapping year shows that the snow from single storms melted gradually for several days in the Coldwater drainage, and it is unlikely that the sand in the trap represents a snowmelt. The sand might have been supplied during a particularly severe storm in March 1983 (the Teflon markers preclude the December and January storms as possibilities). More likely, the coarse sediment was suspended from a local slope failure, probably beneath the water, along the steep sides of the lake. Slope failure has produced turbidites and introduced coarse sediments in steep-sided lakes of similar depth (Ludlam, 1974).

\section{SEDIMEN]Г YIELD}

An estimate of sediment yield was obtained from the volume of sediment accumulated in the delta of South Coldwater Creek. The Corps of Engineers surveyed the area of the delta in April 1981 before the lake rose to its present level, which is $14 \mathrm{~m}$ above the delta base. A volume was calculated on the basis of a thickness of $14 \mathrm{~m}$, changes in delta area between April 1981 and March 1983, and an assumed density for the sediment of $1.5 \mathrm{~g} / \mathrm{cm}^{3}$. The daily yield from the South Coldwater drainage was $90 \mathrm{~g} / \mathrm{m}^{2}$ for the 700 -day interval. This daily rate was reduced to $68 \mathrm{~g} / \mathrm{m}^{2}$ from July 1982 to March 1983. The sediment yield calcu- 


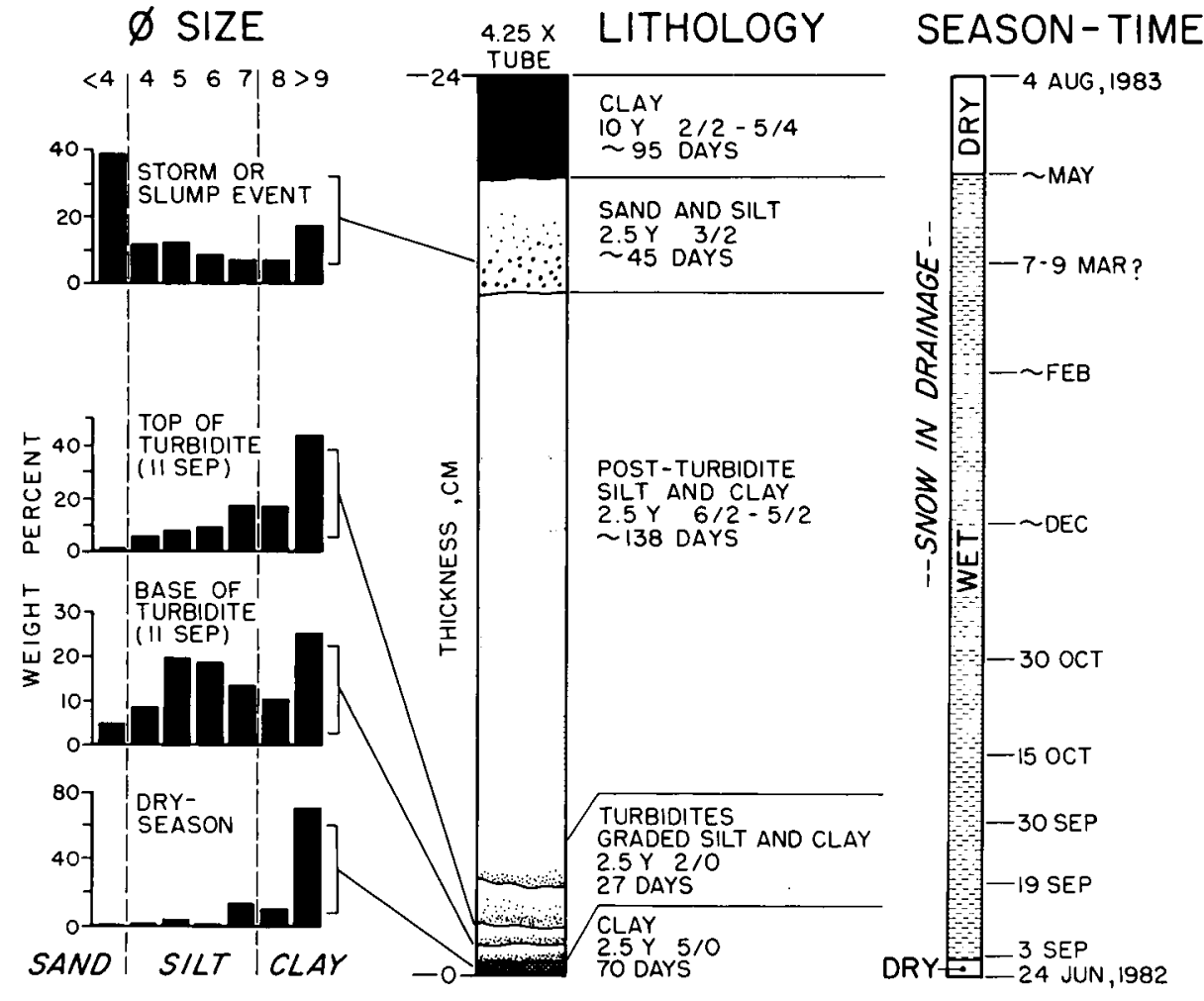

Figure 3. Diagram of $4.25 \times$ sample tube showing time relationships and sediment sizes.

lated for the delta is a minimum estimate, as an unknown amount of material bypassed the delta.

Sediment yield at the trap locality was calculated assuming that the sediment was derived from the first- and second-order streams of the $12.6-\mathrm{km}^{2}$ basin that drain directly into the lake. Although some sediment bypassed the deltas of the two major streams, this contribution was excluded from the calculations and the totals in Table 1. Unpublished sediment-trap studies by us in Pyramid Lake, Nevada, show that fallout beyond the delta from the sediment plume on the surface of that lake was reduced by half at $1 \mathrm{~km}$ from the delta and by three-quarters at 2 $\mathrm{km}$. The Coldwater traps were located $2.5 \mathrm{~km}$ from the edge of the South Coldwater delta and $3.4 \mathrm{~km}$ from the Coldwater delta. If the Pyramid Lake relationship is valid, it means that the estimates based on the area drained directly by the lake are no more than one-third higher than for all the drainages combined.

The delta and trap calculations provide only minimum estimates of sediment yield. The trap information is mainly of value in estimating yields associated with specific storms and changes with the seasons. However, some idea of total annual sediment yield and rates of denudation can be obtained from the minimum estimates and by making certain assumptions. Annual sediment yield for South Coldwater drainage on the basis of delta volume is about 25000 metric tons $/ \mathrm{km}^{2}$. This translates to a denudation rate of $1.6 \mathrm{~cm} / \mathrm{yr}$. If it is assumed delta, the rate of denudation of $2.3 \mathrm{~cm} / \mathrm{yr}$ approaches the $2.5 \mathrm{~cm} / \mathrm{yr}$ obtained by measurement of sheet and rill erosion in the devastated area between 1980 and 1982 (Swanson et al., 1983). A similar rate of denudation of 2.4 $\mathrm{cm} / \mathrm{yr}$ is obtained from the trap data by adding a one-third contribution of sediment from the Coldwater and South Coldwater drainages and accepting the estimate from the core locality that the trap sampled one-sixth of the sediment carried to the site.

\section{COMPARISONS WITH OTHER DRAINAGES}

Sediment yield into Coldwater Lake is two orders of magnitude greater than observed in vegetated drainage basins of similar size and with similar relief/length ratios (Hadley and Schumm, 1961). The probable rate approaches the extremes associated with gullying in basins of much smaller size (Schumm, 1963). The rate is also two orders of magnitude greater than the maximum yield estimated by Langbein and that one-third of the sediment load escaped the
Schumm (1958) for undisturbed basins in semiarid climates and in natural basins and reservoirs with equivalent effective precipitation but covered with vegetation. More recent investigations, however, indicate that the Coldwater rate may be only about 10 times greater than average rates for vegetated mountainous areas with steep catchments (Griffiths, 1979). Lack of vegetative cover, combined with steep slopes, gullying of highly erodible materials, and a strong seasonal distribution of precipitation, has led to the high rates of denudation. If the same terrain were covered with vegetation in equilibrium with the climatic setting, the yield would probably be reduced by an order of magnitude, as suggested by comparing yields in uncut vs. harvested forest terrain (Nolan and Janda, 1981).

\section{IMPLICATIONS FOR VARVE FORMATION}

The blast and the instantaneous clearing of vegetation produced a mismatch between vegetation and climate and initiated a natural experiment that provides additional information about the contrast in sediment delivery between climatic areas of low and high precipitation (Malling and Kleo, 1979). The seasonal shift from turbidite to nonturbidite deposition, followed by the slow accumulation of clay, was a consequence of the strongly seasonal distribution of precipitation. During the dry season, surface materials became less saturated and the runoff threshold was increased, thereby accentuating the "first flush" of sediment transport at the onset of the next wet season. This response is not unique to physiographic areas with high precipitation. A "first-flush" effect was observed in a sediment trap $4 \mathrm{~km}$ from the delta edge in Pyramid Lake, Nevada (Anderson, 1977). However, the well-developed summer dry period in southwestern Washington and the arrival of storms on a regular schedule assure that turbidites and silt-clay couplets will be deposited once every year. These couplets would be considered varves in the geologic record.

The deposits in Coldwater Lake show the type of sedimentation to be expected in a wetdry climatic setting when abundant material is available for transport. Texturally and structurally, the laminated and graded silt layer and the silt-clay couplets bear a close resemblance to some of the graded clastic varves forming in proglacial lakes such as Lake Louise, Alberta (Johnston, 1922), and Skilak Lake, Alaska (Perkins and Sims, 1983).

Glacial varves are characterized by uniformity of structure and thickness from year to year, and these properties, as much as internal grading, lead to recognition of them (Antevs, 
1925). Persistent seasonal forcing, which helped produce long, uniform sequences of glacial varves through ice melting, is also a characteristic of precipitation in several climatic regimens, especially in the middle latitudes. The second year of trapping in Coldwater Lake, from August 1983 to August 1984, produced a sedimentation response that was virtually identical to that of the first year. The first storms of the 1983 wet season formed turbidites that were only slightly less distinct than those formed in 1982 , perhaps because returning vegetation was beginning to inhibit the "first-lush" effect. The second-year accumulation was $70 \%$ of the first year.

If vegetation could be held back at Mount St. Helens indefinitely, the regular pattern of seasonal precipitation would produce a long, uniform sequence of graded varves similar to those found in a glaciolacustrine setting. Perhaps the common occurrence of long sequences of thick, uniform, graded and laminated clastic varves in the Precambrian reflects several modes of formation (Pettijohn, 1957) and climatic parameters, including seasonal air-mass movements and precipitation. The Mount St. Helens experiment suggests that these conditions might be met in certain geologic-climatic settings before the development of soil-binding terrestrial vegetation.

\section{REFERENCES CITED}

Anderson, R.Y., 1977, Short-term sedimentation response in lakes in western United States, as determined by automated sampling: Limnology and Oceanography, v. 22, p. 423-433.

Antevs, E., 1925, Retreat of the last ice sheet in eastern Canada: Ottawa, Geological Survey of Canada Department of Mines, Memoir 146.

Griffiths, G.A., 1979, High sediment yields from major rivers of the western Southern Alps, New Zealand: Nature, v. 282, p. 61-63.

Hadley, R.F., and Schumm, S.A., 1961, Sediment sources and drainage basin characteristics in upper Cheyenne river basin: U.S. Geological Survey Water Supply Paper 1531-B, p. 137-196.

Johnston, W.A., 1922, Sedimentation in Lake Louise, Alberta, Canada: American Journal of Science, ser. 5, v. 4 (23), p. 376-386.

Kidd, D.E., and Potter, L.D., 1978, Analysis of metal cations in Lake Powell ecosystem and tributairies: University of California at Los Angeles, Institute of Geophysics and Planetary Physics, Lake Powell Research Project Bulletin, v. 63 , $170 \mathrm{p}$.
Langbein, W.B., and Schumm, S.A., 1958, Yield of sediment in relation to mean annual precipitation: American Geophysical Union Transactions, v. 39, p. 1076-1084.

Ludlam, S.D., 1974, Fayetteville Green Lake, New York; 6 . The role of turbidity currents in lake sedimentation: Limnology and Oceanography, v. 19 , p. 656-664.

Malling, D.E., and Kleo, A.H.A., 1979, Sediment yields in areas of low precipitation: A global view, in The hydrology of areas of low precipitation (Proceedings, Canberra symposium, International Association of Hydrological Sciences): Washington, D.C., IAHS-AISH Publication 128, p. 479-493.

Nanson, G.C., 1974, Bedload and suspended-load transport in a small, steep, mountain stream: American Journal of Science, v. 274, p. $471-486$.

Nolan, K.M., and Janda, R.J., 1981, Use of shortterm water and suspended sediment discharge observations to assess impacts of logging on stream sediment discharge in the Redwood Creek basin, northwestern California, U.S.A., in Davies, T.R.H., and Pierce, A.J., eds., Erosion and sediment transport in Pacific rim steeplands (Proceedings, Christchurch symposium, International Association of Hydrological Sciences): Washington, D.C., IAHS-AISH Publication 132, p. 415-437.

Perkins, J.A., and Sims, J.D., 1983, Correlation of Alaskan varve thickness with climatic parameters, and use in paleoclimatic reconstruction: Quaternary Research, v. 20, p. 308-321.

Pettijohn, F.J., 1957, Sedimentary rocks: New York, Harper, 718 p.

Sarna-Wojcicki, A.M., Shipley, S., Waitt, R.B., Jr., Dzurisin, D., and Wood, S.H., 1981, Areal distribution, thickness, mass, volume, and grain size of air-fall ash from six major eruptions of 1980 , in Lipman, P.W., and Mullineaux, D.R., eds. The 1980 eruptions of Mount St. Helens, Washington: U.S. Geological Survey Professional Paper 1250, p. 577-600.
Schumm, S.A., 1963, The disparity between present rates of denudation and orogeny: U.S. Geological Survey Professional Paper 454-H, 13 p.

Swanson, F.J., Collins, B., Dunne, T., and Wicherski, B.P., 1983, Erosion of tephra from hillslopes near Mt. St. Helens and other volcanoes: Japan Public Works Research Institute, PWRI No. 1908, p. 183-221.

U.S. Weather Bureau, 1980, Climatological data annual summary, Washington, 1979: Asheville, North Carolina, National Climatic Center, 19 p.

Waitt, R.B., Jr., 1981, Devastating pyroclastic density flow and attendant air fall of May 18Stratigraphy and sedimentology of deposits, in Lipman, P.W., and Mullineaux, D.R., eds., The 1980 eruptions of Mount St. Helens, Washington: U.S. Geological Survey Professional Paper 1250 , p. $439-458$.

\section{ACKNOWLEDGMENTS}

Support was provided by National Science Foundation Grant EAR 81-13072. We thank Karl Lee, U.S. Geological Survey, for providing precipitation data; the U.S. Geological Survey staff at Vancouver, Washington, for logistical support in the field; Gregory DelMastro and Charles Stamschor, University of Wisconsin, Platteville; Shirley Adams, University of New Mexico; and Michael S. Anderson for assistance with field work and laboratory analyses.

Manuscript received July 3, 1984

Revised manuscript received January 21, 1985 Manuscript accepted February 7, 1985 